\title{
Apresentação - Diferença, cinema e educação: 0 que há de pergunta nesta composição?
}

\section{Presentation - Difference, cinema and education: what enquiry is there in this composition?}

https://doi.org/10.34112/2317-0972a2018v36n73p13-15

Anelice Ribetto ${ }^{1}$

VALTER Filé ${ }^{2}$

O dossiê que ora apresentamos pretende, primeiramente, materializar aquilo que perpassa todos os textos e os desejos dos seus autores: gestar encontros singulares. Encontros entre seres humanos que, diante das misérias vividas na contemporaneidade, não esmorecem e continuam pretendendo que seus esforços estejam em favor do surgimento de outras formas de pensar e de viver o mundo. Outras formas que questionem aquelas que pretendem a diferença como a identificação de alguns como diferentes, como fontes de todo o mal (ou de toda a falta) e que devem ser tratados como desiguais. Para tais concepções, os encontros nunca são singulares, pois o outro já é conhecido, já se sabe o que esperar dele, já se tem uma forma de olhá-lo (ou de desviar o olhar), já se conhecem de antemão as formas de tratá-lo.

Diferença, cinema e educação são os fios sugeridos para a trama dos encontros entre sujeitos, sensibilidades e energias. Escritos que pretendemos que continuem se adensando, na medida em que, como mensagens colocadas em garrafas jogadas no mar, encontrem outros sujeitos com suas sensibilidades e energias... e continuem reverberando, contagiando, produzindo encontros singulares e conversas entre desconhecidos.

1. Universidade do Estado do Rio de Janeiro, Rio de Janeiro, RJ, Brasil.

2. Universidade Federal Rural do Rio de Janeiro, Nova Iguaçu, RJ, Brasil. 
Os envolvidos nesta empreitada tomaram, de alguma forma, a educação como dimensão possível para dar a ver o encontro do cinema com as questões que ainda precisamos tratar, com relação aos modos de lidar e de compreender a diferença, e, principalmente fazer ecoar uma pergunta: O que há de pergunta nesta composição?

Passamos agora ao trailer, que pretende apresentar os textos-cenas e algumas das condições de possibilidades abertas pelos autores.

"Nosotros y losotros: diversidad y cuidado de sí y delotro" é um texto-cena que coloca o próprio cinema, na relação com a diferença, como campo de experiência. Alerta-nos que não se trata do filme em si mesmo, senão o modo de nos acercarmos dele, de apreendê-lo e de torná-lo mais um dispositivo que possa habilitar o pensamento a pensar. $O$ pensamento, neste caso, não é tido como uma mera atividade intelectual, mas como a emergência de um saber vital, no qual se entrelaçam o afetivo, o sensível e o cognitivo. Considerando assim, o pensamento vivo não tem fronteiras, nem sabe de categorias a priori. Funciona por composição, gera conexões, cria configurações. Enquanto o raciocínio articula por marcos teóricos ou modas acadêmicas, o pensamento se desdobra desde o desejo e conecta-se com o que é afim, gestando uma ética dos encontros.

"Boca de lixo: o outro, o nome e o encontro" enuncia-se como um esforço para pensar a arte de fazer do cineasta Eduardo Coutinho. A partir do documentário Boca de lixo, pretende-se abordar os sentidos e os efeitos que algumas das suas passagens permitiram aos autores para ampliar um conceito fundamental para lidar com a diferença em educação: o encontro. $\mathrm{O}$ encontro como espaço de conversação e como contorno metodológico possível para as pesquisas que interpelam a diferença e as relações de alteridade como questões fundamentais para o campo da Educação.

O filme Billy Eliot aparece no dossiê como oportunidade de colocarmos o pensamento sob suspeita. Assim, "Fazendo e desfazendo gênero em Billy Elliot" desenvolve-se a partir de perguntas do tipo: por que pensamos o que pensamos? Como nossos pensamentos organizam nossas ações no mundo e nossas relações pessoais? A partir do drama cinematográfico, o texto traz para a cena aspectos da construção dos gêneros pela perspectiva de Judith Butler, ou seja, o modo como o masculino pode ser entendido dentro do projeto de fazer e desfazer o gênero.

Minhas tardes com Marguerite, filme de Jean Becker, oferece-nos uma aproximação ética, estética e política com a formulação foucaultiana de escrita de si. O texto "Por entre tardes e os efeitos dos encontros com Marguerite ou dos descaminhos de uma ethopoiesis de si" aposta na tessitura de bons encontros para problematizar uma prática 
de constituição de um sujeito ético no presente. Encontros são tomados, como propõe Gilles Deleuze, como o que pode fazer vibrar e revigorar a força de um acontecimento.

"Quando ainda não existia a palavra: $\mathrm{M}$ - O vampiro de Dusseldorf” é um ensaio que provoca a pensar acerca dos processos educativos a partir do envolvimento do cinema como um dispositivo que compõe as redes educativas de docentes e discentes, nos projetos de pesquisa "Redes educativas, fluxos culturais e trabalho docente - 0 caso do cinema, suas imagens e sons" (2012-2017) e "Processos curriculares e movimentos migratórios: os modos como questões sociais se transformam em questões curriculares nas escolas" (2017-2022), desenvolvidos com a criação de cineclubes, esses 'praticantes pensantes' das escolas, em alguns municípios do Rio de Janeiro.

O cineasta Eduardo Coutinho aparece mais uma vez com o seu Jogo de cena, filme que os autores do texto "Ética como jogo de cena" utilizam para propor questionamentos acerca das posturas dominantes de interpretação sobre o sujeito de uma história narrada. E ainda, a lida com outras possibilidades de sentido do que seja a alteridade no convívio com a diferença. O filme, ao situar a fala como um jogo aberto, se desloca da busca de uma estável verdade sobre si que o outro revelaria, propondo um deslocamento que desprivatiza a esfera do íntimo, possibilitando a produção de uma obra aberta.

No texto-cena seguinte - "Heterotopias e trajetividades: lugares para as diferenças nas subjetividades nômades" - sugere-se a ideia de heterotopias e trajetividades como noções importantes para pensar as diferenças no sentido de experiências de subjetividades nômades. São duas experiências cinematográficas: Omar e The giver ( $O$ doador de memórias). Experiências que atuam como agenciamentos de signos da arte que se busca ao longo do texto. Em um primeiro momento, desde uma hipótese proustiana, busca-se entender o que são experiências com as heterotopias e as trajetividades, sobretudo a partir do filme Omar. Em segundo lugar, a partir de uma questão extraída do filme The giver, explora-se como o campo problematizador das diferenças pode ser afirmado entre a confrontação da máquina de produção de subjetividade sedentária e a máquina de produção de subjetividade nômade.

As pessoas que acudiram ao convite para a produção deste dossiê foram provocadas a compor a partir do seguinte mote: "Diferença, cinema e educação: o que há de pergunta nesta composição?". Seguem, então, os efeitos dos nossos encontros e da alegria da renovação da amizade e do cuidado que devemos a nós mesmos, ao Outro e ao mundo.

Eis o que foi possível oferecer como abertura para outros encontros singulares. 